\title{
Aromanian Language
}

National Cancer Institute

\section{Source}

National Cancer Institute. Aromanian Language. NCI Thesaurus. Code C154102.

An Eastern Romance language spoken in Southeastern Europe. 